\title{
Environmentalism and Democracy
}

Pragmatist Perspectives on a Precarious Relation

Ana Honnacker

\section{(2) OpenEdition}

\section{Journals}

Electronic version

URL: http://journals.openedition.org/ejpap/2132

DOI: 10.4000/ejpap.2132

ISSN: 2036-4091

Publisher

Associazione Pragma

Electronic reference

Ana Honnacker, « Environmentalism and Democracy », European Journal of Pragmatism and American Philosophy [Online], XII-2 | 2020, Online since 14 December 2020, connection on 15 December 2020.

URL : http://journals.openedition.org/ejpap/2132 ; DOI : https://doi.org/10.4000/ejpap.2132

This text was automatically generated on 15 December 2020 .

\section{(c) $(1) \odot$}

Author retains copyright and grants the European Journal of Pragmatism and American Philosophy right of first publication with the work simultaneously licensed under a Creative Commons AttributionNonCommercial-NoDerivatives 4.0 International License. 


\title{
Environmentalism and Democracy
}

\author{
Pragmatist Perspectives on a Precarious Relation
}

\author{
Ana Honnacker
}

\section{Introduction: Too Little, Too Late?}

1 With the Fridays for Future movement, environmental activism reached another level. What started with a single young Swedish woman skipping school once in a week in order to protest against climate change became a global phenomenon quickly: Young people from all over the world followed Greta Thunberg's example and joined for "school strikes for climate" every Friday. The strikes got increasingly more media coverage, and so did climate change itself. Not only the public awareness grew, but also the public support. On September 20th 2019, at least 4 million people were on the streets all over the world, marching for an environmental policy that does no longer ignore the crisis of global warming any longer and responds adequately.

2 The sheer mass of people combined with the fact that the protesters represented not only a small "green" community but were of all ages and came from all kinds of social and political backgrounds engendered political pressure. If ecological issues appear as demands brought forward only by special interest groups, they can easily be treated as incommodious appendixes in political debates (if they are discussed at all). If they are, instead, articulated by a broad coalition of citizens, it is far harder to mark them as elitist. If, then, environmental questions are presented as questions of common good as well as self-fulfillment, of justice and well-being and - in the long run - even bare survival, it is rather striking that they haven't been a major concern (and more: at top of the political agenda) for most nations for the most part. This is especially true for democratic societies.

3 For some of those who strive for "greener" politics, the last observation sheds doubt on the capability of democracies to deal with the climate crises properly. Whether it is due to a lack of willingness to risk re-elections by drawing unpopular decisions on the side of politicians or because of the myopic focus on economic well-being and personal freedoms (like buying and driving SUVs or eating cheap meat) on the side of the 
citizens, or a mixture of both - democratic systems seem to fail in face of large-scale and apparently distant problems. This alleged failure can be described in terms of efficiency and morality, and often both aspects mingle in feeding the "green skepticism" towards democracy. Whereas the first reservation aims more at the functional level, assuming that democratic procedures are inert and dependent on the public opinion in a way that determines them to respond "too little, too late," the second reservation questions the intrinsic value of democracy.

4 Especially with regard to a certain frustration within environmental circles, the longing looks in the direction of states like China or Singapore which have the political means to implement environmental policies rather authoritarian, and therefore quick and efficient, are no big surprise. ${ }^{1}$ Yet there are also much stronger and more explicit claims that present democracies, or even democracies in general, are not able to do what is necessary (and also morally right) with regard to our dealings with the environment and future generations. Roger Hallam, co-founder of the more radical movement Extinction Rebellion, produced popular outrage when he stated in an interview: "When a society engages in morally corrupt activities, democracy becomes irrelevant."

5 Although there are good reasons to understand statements like these not as blunt rejection, but as radical criticism of environmental politics pursued by current democratic governments, and therefore as an attempt to realize more democratic politics, ${ }^{3}$ they are often taken as evidence of anti-democratic tendencies in environmentalism. This paper will, in a first step, examine those traits in environmental thinking that suggest to see it in conflict with democracy.

Drawing on what can be learned from their sometimes harsh criticism of democratic politics as well as from an analysis where they really depart from democratic grounds, the elements of an "ecological democracy" will be outlined in a second step. If we follow the pragmatist idea that democracy is, on the one hand, the best way of organizing a society in order to pursue collective problem-solving, and, on the other hand, has an intrinsic value as a form of life that allows for a maximum of selfrealization and at the same time fosters the common good, deepening democracy is a precondition for tackling the environmental crisis. We need a fundamental transformation that has to be not only accepted but actively designed and supported by (and, indeed lived by) citizens.

\section{Environmentalism and Democracy: Criticism and Departures}

7 Since the beginnings of the environmental movement, its relation to democracy was contested, both by its proponents and its opponents. Though there is no unified environmentalism in the sense of a systematic and coherent theoretical framework, it may be said that the diverse rationales, be it in philosophical accounts or mission statements, have a common direction of impact: they object to the status quo. The way we handle life-sustaining resources, the way we trade, consume, eat, move, the way we relate to other-than-humans, in short: the way we treat nature, is questioned and the need to act differently is stated. Consequently, activist as well as theorists have to take position with regard to how to induce change in behaviour, or how to implement more 
environmental-friendly laws, that is, they have to choose their (in the widest sense political) means.

8 An underlying motif of arguments against those challenges of the state of things is the reproach of a general anti-liberal thinking. Environmental demands are said to be restrictions that conflict with the individual interest and thereby the freedom of the citizens. Rather mild suggestions like that of one vegetarian weekday in public canteens ("Veggieday") or a limitation of speed on highways brought forward by the German Green Party were massively objected as manifestations of a culture of prohibition and first steps towards an "eco-dictatorship" or at least potentially authoritarian. Even the label "eco-fascism" turned up (as it does reflexively and reliably whenever regulations are imminent).

9 In what follows, I will focus on those strands of ecological thinking which are at odds with democracy, either explicitly or implicitly, since they reveal the particular soft spots that have to be addressed and handled when it comes to environmental political action.

\section{1. "Eco-Fascism"}

10 Maybe the most prominent anti-democratic attribution to environmentalism is that of purporting a "green" dictatorship or even fascism in the name of ecology. Facing the failure of liberal democracies to enforce better instruments to protect the environment, calling for a "strong state" may be a continuous (and growing) temptation. In order to protect survival, some play with the idea of a rather authoritarian regime which acts in the line of a declared state of emergency and controls public life, restricts fundamental rights and allots resources, if necessary by force. ${ }^{4}$ I will elaborate on those actual tendencies later.

11 Yet the term "eco-fascism" transports another, even more severe reproach: environmentalism's potential support of fascist/Nazi ideology (Zimmerman 2000; Ferry 1995). This applies specially to approaches that hold a holistic and rather spiritual attitude, for example deep ecology or other rather ecocentric currents. Critics are eager to point to and warn against their "dark side." The claim of the affinity of holistic environmentalism to fascist ideology mainly refers to the romantic and anti-modernist attitudes often displayed in these approaches on the one hand and to the ecological dimension of Nazism on the other hand.

12 Undeniably, one of the many historic origins of environmentalism is a defensive reaction to the industrialization and, more broadly, modernization (Radkau 2012: 254-60; Barry 2014: 155). This line entails romantic and spiritual features, like a resacralization of nature, that may turn into an explicit anti-modernism and even antirationalism. Despite the fact that there are some overlappings of green thinking and right-wing extremism, a closer look reveals a rather weak link that is far from making a point against environmentalist thinking, even in its holistic and spiritual variants.

13 First, the reproach rests on a simplified idea of fascism (Plumwood 2000: 70-6). Moreover, the "green" side of Nazism is overstated. The "blood and soil"-ideology of the Third Reich indeed drew on ideas of autarchy and subsistence and displayed a kind of timely ecological awareness (“ökologische Geistesgegenwart," Radkau 2012: 294). It used the strong emotions of frustration prevalent in the German population and sought to channel them into a nationalist love for the homeland and its landscape. 
Furthermore, certain anti-modernist and pagan elements surely played a role in Nazi ideology. Nevertheless, it also was progressivist and rather relied on technology. Natural resources were heavily exploited for armament. Autarchy was propagated in order to prepare the war. In sum, the concrete politics of the Third Reich wasn't "greener" than the Weimar Republic (Radkau 2012: 260-73, 294-8).

Even if twentieth century fascism could be taken as most extreme example of "ecological identity politics," not any form of ecological thinking that underlines the commitment and bonding to a specific place and/or community leads to exclusive - or even xenophobic - political action. Nevertheless, ideas of "native" landscape and untouched wilderness are dangerously close to that of purity and provide it with a "natural" grounding. Evoking strong affection for a particular environment bears the danger of feeding also reactionist feelings. ${ }^{5}$ Then, the preservation of ecosystems blends with the preservation of one's own community, or even "race," and the protection of one's homeland seems to suggest keeping out foreigners, be it invasive animals or immigrants - both "do not belong." Bioregionalism, or other movements that strongly rest on ecological identity politics, thus are in danger of leading to a "culture of nature" that is exclusive, xenophobic, and undemocratic. ${ }^{6}$ Though these affinities must not be downplayed, charging environmentalism in general of fostering "eco-fascism" and building a green dictatorship must be considered an attempt of discrediting environmental thinking and, most important, environmental political action.

Still, beyond those red herrings, there are actual and more pressing anti-democratic tendencies in environmental thinking. In what follows, I will highlight three problematic aspects: First, a certain inherent affinity to revolutionary and anarchist thinking is pointed out. Second, I will take a closer look at different lines of paternalism and authoritarianism. Third, the political implications of the widespread nonanthropocentric ideal are examined.

\subsection{Bringing Down the System: Revolutionary Action}

A first potentially anti-democratic feature may be found on the level of the mode of political action. Generally, radical forms of environmentalist thinking tend to have sympathies for anarchism (Barry 2014: 158) and to be politically revolutionary instead of relying on reforms. "Fixing" environmental problems while going on the way we used to seems a "shallow" solution - which means it is no solution at all. From this perspective, we need a thoroughgoing social and cultural transformation. The crucial question is how this demand for change is realized, and how far-reaching it is.

Deep ecology, for example, clearly advocates a radical re-orientation with regard to our lifestyle. Though this implies fundamental political, economic and social changes, deep ecologists remain rather vague about how these are to implement and focus on the importance of an alternative philosophy. The revolution is intended to happen on the metaphysical level: ontology first, politics second. "The advocates of deep ecology claim that the most important task is to understand the world in the right way [my italics]; given the correct understanding, the ethical choices will be obvious." (Katz, Light \& Rothengerg 2000: xiv). ${ }^{7}$ This openness leaves room for anti-democratic political action yet it does not explicitly support it, the more so as it is conceded that the 
necessary deep change may be performed in small steps, and is only revolutionary "in direction" (Naess 1989: 156).

The problematic dimension of revolutionary demands become obvious when not only the free market and global capitalism are identified as part of a system that is ecologically disastrous but also the existing institutional and political structures, including democracy. In contrast to reformist environmentalism, the criticism of "the system" is totalized, hence the necessity of a system-change is claimed (Westra 1993: 126).

The radical movement of anarcho-primitivism is probably the most significant manifestation of that kind of criticism. According to its proponents, civilization itself is the root of our social and environmental problems, since it has alienated us from ourselves and the environment. Apart from mediation and technology, what deprived humans from "what's real" and valuable is the "ideology of civilization," which raised false and perverted desires and must be fought in order to be authentic again. This ideology is 'based upon deep rooted notions of 'progress,' the value of consumption and work, domestication and order, and the underlying desires created by industrial society" (Humphrey 2007: 34). State, capital, organised religion, technology, in short: civilization, is said to facilitate oppression, alienation, domestication and exploitation. In consequence, it has to be abandoned respectively destroyed. Furthermore, primitivism rejects politics in all but anarchic forms and advocates the absence of political authority (Humphrey 2007: 31-9; Aaltola 2010: 164-6). The revolutionary impetus of anarcho-primitivism thus is not only anti-civilizatory, but anti-democratic and finally anti-political at its core.

\section{3. "What Must Be Done, Must Be Done!" - Green Authoritarianism}

A second source of anti-democratic sentiment in environmentalist thinking can be found in its tendency to become paternalistic and authoritarian. Among environmentalists, there is a widespread, sometimes even hostile skepticism with regard to the capacity of democratic governments to implement "green" politics, that is, to do "what needs to be done" (Norton 2002: 22; Leist 2005: 441). In short, this feeds into the wider narrative of the inability of democracies to solve complex problems which strongly undermines their legitimacy in terms of output: Democracies do not (or at least, not any more) "deliver" (Leggewie \& Welzer 2010: 137). This skeptic attitude is fed by several, often intertwined sources, and I will briefly outline the two most popular motifs: the assumptions that democratic processes are too slow, and that citizens are neither competent enough nor willing to support more restrictive policies.

21 The first reservation is due to a "sense of urgency," caused by the idea of an "imminent environmental catastrophe" and "the belief that time [is] running out fast" (Humphrey 2007: 12). Eco-authoritarians, or "survivalists," are convinced that democracy is just not effective enough to achieve survival and hence must be dismissed. ${ }^{8}$

However, the believe that environmental issues are tackled too little and too late within democratic societies prompts most environmentalists to search for means to nudge them. Consequently, direct action is an essential part of ecological activism. Given that the threat of ecological disaster is enormous, one may argue that a "do or die"attitude is more than fair and that resistance, including violence, is legitimate and even demanded. Whereas critics deplore direct action as anti-democratic "eco-terrorism," 
the vast majority of green political movements and activists see themselves in the tradition of non-violent civil disobedience (Humphrey 2007: 40-62). With the exception of rather radical groups like Earth First!, 9 the Animal Liberation Front or, recently, Extinction Rebellion, the aim of "ecotage" is to enforce laws, yet even when illegal action is part of the agenda and seen as legitimate means, non-violence against human beings remains a central principle. ${ }^{10}$ Thus, direct action is a democratic response to the feeling of being in a state of emergency and a way to come to terms with the inertia of democracy without relying on authoritarian instruments.

Yet the alleged inadequacy of democracy is not only a matter of time. The "antidemocratic despair" is also fed by "the view that ordinary citizens are politically incompetent, especially at times of crisis" (Humphrey 2007: 11). This judgement rests mainly on anthropological assumptions provided by rational choice theory. Democratic decision making is regarded as a problem of collective action. From this perspective, the environmental crisis thus confronts us with a planetary version of the tragedy of the commons. When left to individual choices, the myopic citizens would most probably follow their self-interest instead of voting for more coercive laws or change their behaviour. Even when a democratic value change is considered the improbable but ideal solution, it would still be a long-term solution. That is why those laws, like limitations on rights of property, mobility, and procreation, have to be imposed on people by an elite that knows better (Humphrey 2007: 15-20; Westra 1998). Platon's philosopher king returns in the guise of the "enlightened ecological elite" (Humphrey 2007: 25). ${ }^{11}$

24 These two reasons for turning to authoritarian elitism mingle with another feature of environmentalist thinking that reveals its anti-democratic potential only on closer inspection: the idea of evidence-based, or rather: evidence-determined, action. As a political and social theory, environmentalism strongly draws on the natural sciences (Barry 2014: 156), leading to a strong imperative character of green political theory.

Though this reliance is an important reminder that environmental issues indeed cannot be treated as mere questions of opinion, it also bears the danger of collapsing politics into science. If how to address the ecological crises is considered to be "not just a question of choice in a plural framework of values" (Vincent 2003:182) and becomes a matter of "doing the right thing" instead, the downright call for expertocracy seems to be the best solution.

The idea of a strong, scientist-led state that is able to manage ecological problems is supported by a structural argument for centralism, presuming that large-scale problems need large-scale institutions in order to be addressed successfully (Radcliffe 2002: 21-8). ${ }^{12}$ What is more, technology is an important part of this management by scientific experts. Yet the belief in merely technical solutions not only fails to acknowledge the necessity of a cultural transformation but also amounts to advancing "non-political techno-fixes" (Barry 2014: 170; Oreskes \& Conway 2012: 260-2). This is true for the defenders of geo-engineering (some of them among the proponents of ecopragmatism) but also for a widespread Malthusian thread that runs through environmentalist thinking (Radkau 2011: 158-61). ${ }^{13}$ Hence, such a techno-optimism or techno-fideism, whether in its cornucopian or Malthusian version may foster the general de-politization of a society.

In the end, the idea that science provides privileged access to reality and/or epistemic certainty facilitates sceptic reservations with regard to democracies. Under the 
premises of such an epistemological elitism, it appears as if political action must follow immediately from scientific findings. Yet grounding politics in seeing the world "in the right way" is a problematic naturalization that requires a rather naïve realism. ${ }^{14}$ Referring to an objective natural order and a resulting moral and political imperative seems to be just another version of the naturalist fallacy, and I will later come back to some epistemic caveats that might well brought forward from the pragmatist perspective.

\subsection{Overcoming Anthropocentrism: Other-Than-Humans and Politics}

28 A third potentially anti-democratic element comes along with an epistemic revolution that led to the perhaps most divisive line in environmental philosophy: that of anthropocentrism vs. non-anthropocentrism. The human-centered approach of traditional ethics appeared to be failing in addressing the ecological problems that became more and more obvious during the second half of the 20th century. Even more, it was charged to come with a "human chauvinism" that led to exploitative and destructive ecological behaviour in the first place. The Christian image of man as legitimate ruler over God's creation came under attack for being the original foundation of such a harmful anthropocentrism that continued to be no less effective in its secularized version (White 1967). With respect to its idea of human separateness from and mastery over nature, humanism is often seen as the heir of Christianity. Moreover, teleological thinking converted into a belief in progress, especially one that is driven by science and technology (Gray 2007). Under these premises, the way we relate to non-humans is nearly inevitably presumptuous and finally destructive.

If the human perspective is taken to be the primary one when it comes to moral considerations, their needs and interests will have priority over those of elephants, palm trees, lakes, or the atmosphere - if they are conceded to have interests on their own at all. Their integrity, health and flourishing are only a derivative to that of human beings. Their value is purely instrumental. According to the critics of conventional environmental philosophy, an alternative ethical rationale is needed in order to take care of nature adequately - not only in terms of philosophical reasoning, but also in terms of political action. The human being has to be de-centered, its central position must be overcome in order to tackle environmental problems (Routley 1973, Naess 1989)..$^{15}$

Whether or not a fundamental change from anthropocentrism to bio- or ecocentrism is actually helpful or even necessary for a successful policy change (that is, to a fossil free, sustainable, non-exploitive global economy) must be discussed separately. ${ }^{16}$ Yet the theoretical implications of such a change must be carefully examined with regard to the political level, since there may be some obnoxious consequences when we leave the familiar terrain of the anthropocentric rationale.

31 Our traditional Western understanding of what moral and political agents are is seriously challenged by the imperative to assign moral rights to non-humans, and not only those who are beyond the species-line but even to non-sentient beings and entities. The great majority of political theories define the democratic community, that is, the community of those we have to concern and are obliged to, as a human community. Rights are individual human rights. Non-anthropocentrists demand to 
reinvent politics and expand this community. We need to discuss who/what is the political subject, when it is no longer human beings alone, and gain a more inclusive understanding of the public. How shall we structure the political institutionally? (Cudworth \& Hobden: 154-62). ${ }^{17}$

Apart from the question if the concepts provided by political theory so far endure this expansion, a maximum inclusion leads to conflicts of a new kind. ${ }^{18} \mathrm{~A}$ holistic ecocentrism concedes nature, or, more precisely, ecosystems, a value on its own, independent from its indirect value as a life-supportive function for human beings. Whereas anthropocentrism clearly favours human interests, non-anthropocentrism has to balance interests and values. Even more if it argues for a "biospherical egalitarianism," according to which "everything has the equal right to subsist" (Vincent 2003: 189) and "all natural beings and entities are intertwined, and need to be taken equally into account" (Aaltola 2010: 161).

In the case of more radical ecocentric approaches, the ecosystem becomes morally primary (Westra 1993: 125). The ultimate consequence can be made clear by employing a variant of Richard Routley's "last man" scenario (Routley 1973). It was designed to show the ultimate implication of anthropocentric ethics in a rather drastic way: The last human survivor on earth would be morally right (or at least: not wrong) if he/she would decide to destroy any living being left and make extinction complete. Turning the table, it would be morally right (or even a moral obligation) to reduce the human population drastically if it was clear that the ecosystem would break down otherwise. ${ }^{19}$ Taking the maintenance of the ecosystem as highest priority and pleading for an "environmental triage" entails, as Westra concedes, "adopting a ruthless 'bottom line' mentality" and the "downgrading of all other social causes/obligations if a conflict with survival were present" (Westra 1993: 134).

That is, approaches that give primacy to non-human higher goods, be it nature, biodiversity, or the stability of ecosystems, potentially subordinate individual rights as well as rights of nation states respectively national governments (Westra 1993: 128-32). Our understanding of democracy is seriously challenged by that shift.

\section{Towards an Ecological Democracy}

The examination of those elements of environmentalist thinking which question democracy may have left the convinced democrat as well as the engaged environmentalist perplexed and faced with a seemingly dilemma. Do we have to give up either democratic or environmental ideals? In what follows, I would like to argue that the case is far from settled. As we have seen, there are approaches of environmentalism that are not only sceptical but hostile towards democracy. Still, the actual (historic as well as contemporary) fascist or anarcho-primitivist currents must not be taken as obstructions against a democratic environmentalism in principle. The same is true for the anti-democratic features in other variants of environmentalism. Neither do they necessarily result in or even demand a downright green dictatorship, let alone a fascist regime. Even more, we can learn from their sometimes radical critique and the points of fractures that become visible through them.

The other way round, it would be appealing but simply misleading to assume a direct link between (liberal) democracy and green values: "For greens to somehow show that all democrats must join them in order to be democrats seems too good to be true." 
(Humphrey 2007: 83). The "argument from precondition" (Dryzek 1987) that suggests that an intact ecosphere is as much a precondition for democracy as free speech, is all too generalisable and applies to all forms of government - and finally to every human activity: "It is nor more or less than an anthropocentric argument for sustainability, as is as much a precondition for business, sport, scholarship, and tiddlywinks as it is [for] democratic politics." (Humphrey 2007: 84-5). The argument, thus, is one-directional: it gives good reason for democrats (and any human being) to support green politics but is no argument for greens to be democrats.

With regard to the argument from precondition, democratic and authoritarian governments seem to be on a par. However, looking at the chances of authoritarian regimes to eventually realize green politics, some serious objections emerge. Notwithstanding the dubious idea of a "good" (which means, in this case, "green") autocrat who uses the given mandate in the way hoped for and only in that way, the assertiveness of such power rule is mainly overestimated. What is often neglected in the debate, especially by the proponents of "green dictatorship," is how unlikely it is that an authoritarian regime is able to permanently impose restrictive policies on unwilling people. Ecological politics need the support and cooperation of the population. Transformation works best if it is not only accepted but understood as a common project (Barry 2002: 147; Buchstein 2012: 54-6; Pötter 2010: 27-8; Leggewie \& Welzer 2010: 135). ${ }^{20}$

In the end, the situation is less dilemmatic (which also means: more complicated) than activists and lobbyists on both sides proclaim. At the same time, the relation of democracy and environmentalism remains precarious. We have to concede that there is no set relationship, no guaranteed connection between democratic processes and environmental-friendly outcomes, since deliberative procedures are contingent and uncertain: "Democracy was only ever a tool for the people to express their will. It never determined that will." (Mulgan 2011: 220; Goodin 1992: 168; Minteer 2005: 56). Therefore, in order to strive towards an ecological democracy, it is all the more important to ask what fosters democratization, what preconditions does a lively democratic society rest on?

One important lesson we can learn from the vigorous critique of democracy brought forward by rather radical environmental approaches is that actual existing democracies have large blind spots and deformations. Majority choices and political preferences among citizens seem to be more or less ignorant towards the massive ecological disaster the "modern" way of life causes and that will change the world as we know it - and probably for much worse. Thus, the idea that it is a particular lifestyle that is deeply flawed and must be overcome points to the heart of the problem in a manner of fact.

Though anarcho-primitivism may well be criticized for being naïve and romantic (Aaltola 2010: 175-9), it can provide a mode of critical thinking that seems to be needed in order to achieve fundamental change: "It is not (normally) that proponents of primitivism wish to literally drag human society back to paleolithic forms of life, minus all forms of modern technology. Rather they want people to think outside of a whole set of deeply socialised prejudices and assumptions, and understand how many of the ideas and institutions that 'we' value are actually subtle facilitators of oppression and domestication." (Humphrey 2007: 39). By challenging the habitual ideas of what is "normal," anarcho-primitivism may encourage to pose the question of the good life 
again and find alternative answers. Furthermore, and especially with regard to the authoritarian and anti-liberal tendencies in other currents of environmentalist thinking, the anarchic elements may well be seen as a counterbalance and putting an "emphasis on collectivism, individual freedom and self-fulfilment" (Aaltola 2010: 161).

Another focus must, of course, be on the deliberative processes of democratic societies. I would like to suggest that before we dismiss democracies as unable to respond properly to the ecological crisis, we could consider their failure in setting up an adequate environmental agenda not as due to their being "too democratic," but because of their being not democratic enough. The public discourse and its conditions can be conceived to be the focal point of environmentalist reservations against democracy. Thus, my outline of an ecological democracy aligns to the following questions: How is the public opinion formed, what drives the deliberative processes? Who gets heard und how do we speak?

\subsection{Why Democratic Discourse Matters: Problem-Solving and Participation}

As we have seen, the call for an expertocracy is one expression of the belief that democratic procedures are not efficient. Critics point to the problem of the "uneducated voter," whose myopic choices are even more promoted under the conditions of economically framed ideas of the good life. Second, there is the problem of economic national and, above all, corporate interests. If the deliberative processes of policy-making and decision-making are driven (one could even say distorted) by these two factors, democratic votes tend to be rather populist votes and indeed "inimical to environmental values" (Westra 1993: 129-30).

These two factors are inextricable, since political and economic lobbyists exert massive influence on public processes of opinion making. Especially the proponents of a "free market fundamentalism" seek to undermine trust in scientific findings and thereby discredit calls for environmental regulations as alarmist and anti-liberal (Oreske \& Conway 2012). The public debate is shaped by groups with an ideological agenda. ${ }^{21}$

Against the elitist and authoritarian temptation of an efficient government of experts, philosophical pragmatism provides an understanding of inquiry - and science as a most professionalized mode of that general human activity - that comes with epistemic humility and a fallibilist caveat. Hence, pragmatists are generally modest with regard to the "correct way of seeing things" and abstain from epistemological elitism: neither scientists nor other experts are empowered to claim privileged access to reality. Science cannot tell us how things "really are" - and it cannot dictate political decisions. Though pragmatism certainly calls for giving weight to scientific experts in deliberative processes, it doesn't demand (or even allow for) a "scientification" of politics. Even more, declaring political decisions as unavoidable with reference to science would be revealed as an untenable move of sheer power. ${ }^{22}$

Nevertheless, rejecting any "paternalism of science" does not legitimize to endlessly cast doubt on scientific findings in order to prevent action in their line. "Environmental agnosticism," the choice to wait for ultimate certainty and therefore to remain inactive, is also an action (Kitcher \& Keller 2017: 23-4) - and a harmful one. Following the environmental activist's claim "Listen to the science" on pragmatic grounds would therefore lead to giving experts an advisory role, taking their findings 
seriously, and figure out "what has to be done" in a corporate and democratic process. ${ }^{23}$ That is, with regard to the environmental challenge, the issue of scientific literacy becomes crucial. ${ }^{24}$

Another benefit of endorsing a pragmatist perspective is an understanding of public discourse and opinion-making alternative to liberal as well as authoritarian concepts. Though it seems clear that the public plays a crucial legitimatory role for successful politics, the non-anthropocentric bias in environmental philosophy leads to a vast omission of the idea of public interest in favor of nature's interest. Part of this neglect stems from the assumption that the public interest is the sum of individual preference, which amounts to the conviction that "environmental protection is [...] effectively being held hostage to the preponderance of exogenous and unquestionable consumer demand values" (Minteer 2005: 41).

Indeed, if democratic decision-making is reduced to the aggregation of individual preferences in terms of the homo oeconomicus, we are left to devices as cost-benefitanalyses. Yet purely economic valuation of the environment is highly problematic as underlying rationale. ${ }^{25}$

Against this liberal, individualist model of public interest, the ideal of the common good has been suggested. Yet this alternative becomes problematic when an objective metaphysical understanding is endorsed: the public can not only be mistaken about it interests, but also be overruled by those who claim to have identified it. The common good, then, becomes an instrument for elitist and authoritarian policies (Minteer 2005: $39-43) .{ }^{26}$

The pragmatist, Deweyan concept avoids the problems of the liberal idea of public interest as well as the potentially authoritarian notion of the common good, since it is understood as constructed in the ever-transforming situational context of a community that organizes itself in order to solve shared problems. What is regarded the common good is a provisional result of an open process of deliberation and cannot be set externally (Minteer 2005: 44-50).

Nevertheless, the public is far from idealized. Dewey is well aware of the "eclipse" of the public and its inchoate status (Dewey 1991). Considering the crucial role that is given to the public and public discourse, there are several desiderata. Generally, the actual conditions of the deliberative process must be paid attention to and constantly improved. ${ }^{27}$ Thus, fighting inequality, marginalization and discrimination is a mandatory part of democratization - and should also be part of environmental engagement. Furthermore, the pluralization of the discourse has to be fostered, especially with regard to dissenting voices. ${ }^{28}$ Beyond providing the framework for the best possible public discourse, it is important to highlight the role of the attitude hold by its participants. Against the view of a consumerist, myopic and egotistic individual that will attempt to enforce its particular interests, the pragmatist demands a lot (and assumes the ability of citizens to meet that demands): willingness to change one's mind during the deliberative process, listening to alien demands and broadening one's own interest (Minteer 2005: 46).

51 In a nutshell, philosophical pragmatism supports the idea that democratic deliberation is the best way of addressing the global environmental challenge. If we understand environmental problems as highly complex political problems that require a high level of creative and cooperative problem-solving as well as the best possible results of decision-making, we need not only the broadest possible community of inquirers, but 
also the integrative and transformative function of democracy (see, for example, Dryzek 1987). Thus, over and above giving a very basic epistemological argument in favor of democracy, the intrinsic value of public discourse is highlighted: beyond contributing to solving a problem, it is the very fact that people can have their say, engage in a common project and build a community, that makes it desirable.

The mere experience of being part of the process, in contrast to achieving a certain outcome, is a good in itself, as it is able to induce the feeling of self-efficacy and thereby counteracts political apathy. Hence, participation is not alone a vehicle for getting "better results," but increasing it is to be named as a crucial dimension of "more" democracy (Leggewie \& Welzer 2010: 149; 172-3).

On the one hand, this has implications on the institutional level: means like mediation, citizen forums, referendums and initiatives have to be implemented in order to encourage and enable participation (Smith 2003: 77-102). Yet active citizen participation is not only a question of "formal" democracy, but of a "personal" one, of democracy as a way of life. It supports the development of democratic habits, the experience of self-governance and building a democratic "spirit" that is necessary to resist antidemocratic forces and foster institutional democratization. Thus, participation is essential for deepening democracy: individual potentials are released and cooperations can be forged - which leads not only to a better handling of problems but also changes the community culture which in turn may have effects beyond a particular community (Green 1998: 232-41, 247-9). Local participation builds democratic citizen skills and has translocal implications: acting locally enables ambitious global transformations (Green 1998: 227; Light 2002: 170).

Yet the acceptance, and more: the active endorsement of environmental policies rests not only on taking part in the deliberative processes. What is also needed is a feeling of environmental responsibility, a "sense of stewardship" (Light 2002: 157). In other words: people need to care about their environment. The most urgent question thus may be how to make environmental questions a matter of concern for citizens. Why should people care about such an abstract thing as nature? Providing facts and information is an important part of creating responsibility, but not sufficient. Rather, it takes "a bond of interest between local communities and the nature around them" (Light 2002: 158). Engaging in a participatory relationship with nature, for example by way of local environmental projects, prevents potential free-riders and creates an intrinsic motivation in citizens. ${ }^{29}$ Aiming at such a democratic "ecological citizenship" (Light 2002) thus is confronted with "the new problem of dirty hands" (Light 2002: 168): the challenge to get more people involved in direct environmental practices.

\subsection{Who Gets Heard? Broadening the Conversation}

Besides the condition of public discourse, its scope must be reconsidered. If we need "a gigantic conversation" (Kitcher \& Keller 2017: 84), who is part of the ideal community? Following the idea of a "democracy of the affected" (Eckersley 2000), the synchronic as well as the diachronic axis will have to be prolonged.

Given that current environmental policies have a huge impact on future generations, we need to question democratic decisions and practices with regard to intergenerational justice. In a way, democratic procedures disfavour future interests: they neither have a vote nor are they represented. The systemic neglection of the 
future becomes manifest in the focus on the next election and the unwillingness to consider a sustainable economic policy. In addition, the practice of discounting future costs and benefits shows a strong bias for present people. Relying on the moral commitment to following generations obviously proved not sufficient, and especially the idea that each generation will turn out better than the last, that is, the belief in endless growth, turned out at least dubious. Not only does the current decisions decrease future options, they even create irreversible facts and constraints of action (Mulgan 2011: 212-20; Leggewie \& Welzer 2010: 157-9, 224). If reversibility is understood as a central feature of democratic decisions, present environmental and economic policies are deeply undemocratic.

Furthermore, broadening the conversation means to make the public discourse as inclusive as possible. Westra articulates the need to "speak out on global issues beyond the reach of democracy or other political systems within which they reside," and demands an "enlightened public" that consists of "educated and aware cosmic citizens" (Westra 1993: 135). Though actual discourse is always restricted by time and space, the question who is to include emerges with new urgency when it comes to environmental issues, and non-anthropocentric approaches remind us of that.

When it comes to voting for environmental policies, adapting Rawls could provide an imaginary means to consider more interests and arrive at fairer decisions: behind an extended global veil of ignorance, the voters have to imagine themselves not only ignorant of their race and gender, their social, national and historic position, but also of their species (Westra 1993: 135; Mulgan 2011: 173-84; Gottlieb 2019: 86).

Still, if we are to build a democratic ecological community, the question of how to expand the range of whom we consider our fellow-beings remains crucial. Whether pure representation and compassion is enough for this cause, or if we need role-taking or even identification (Naess 1989: 171-6), and if this a possible move at all without being chauvinist again is highly debated. How can we achieve solidarity without colonizing other-than-humans? Environmental philosophy could learn from feminist and anti-colonial theory here and adopt an idea of the other that includes sensitivity for otherness and difference and at the same time abstains from dualistic "hyperseparation" (Plumwood 2000: 61-70). Inspired by difference theory with regard to minorities and marginalized groups, ${ }^{30}$ consulting future generations and non-human nature could be an important step to "greening representative assemblies" (Smith 2003: 111-24). So, extending the moral community beyond the human community and thereby "greening" the state may well move it beyond the liberal model. ${ }^{31}$

Another dimension of broadening the discourse and renegotiating who gets heard is marked by the question how to deliberate. Against the idea of a purely rational reasoning that is led by universal principles and logical conclusions, deliberation may also include emotions and narrative elements. Given that participants are not distanced and indifferent with regard to the subject of the conversation, telling the full story is crucial for achieving a reciprocal understanding of adversary positions: "Expressions of anger, grief, fear, confusion, joy, and gratitude are not distractions from a democratic deliberation, but an essential part. They give us insight into why something may be crucially important to us or our fellows." (Gottlieb 2019: 64). We need to know what drives other persons, what matters to them, in order to develop empathy and solidarity despite the differences. The enrichment of communicative styles beyond the rational (and perhaps even the verbal) mode may also facilitate the extension of democratic 
deliberation beyond humans: "In this admittedly expanded sense of democratic conversation, we might encounter, for instance, the melting of glaciers due to global warming, the rash of pollution-caused birth abnormalities in frogs, or the emotional devastation of animals kept in zoos. We might encounter, that is, an ecological democracy." (Gottlieb 2019: 66). This ecological democracy relies on the human ability to form a bond without verbal communication, though knowledge continues to play an important role for "listening" to non-human nature. That is, being part of that ecological democracy requires "that we learn to pay attention to what nature is saying to us: both by awareness of reasonably accessible scientific knowledge and by a process of attunement to plants, animals, and ecosystems" (Gottlieb 2019: 73-4). ${ }^{32}$

61 Whereas a blunt biospherical egalitarianism challenges the conventional architecture of democracies, a "weak anthropocentrism" could be a viable option and is fully in line with the pragmatic tradition (Norton 1984). The problems of non-human agency and political representation that come with a full-blown shift to an ecocentric perspective (Cudworth \& Hobden 2011: 150-4) can be evaded by such a position: "We will continue to eat, use, and compete with nature, trampling on insects or uprooting plants in ways that would not be morally acceptable if done to people." (Gottlieb 2019: 71-7).

Still, such an "environmentally enlightened anthropocentrism" (Smith 2003: 13) involves at least the recognition of the instrumental value of non-human nature. We are dependent on environmental conditions: Not only are they life-supporting, nature also has a value for our identity and well-being, and acknowledging this can be a strong rationale for the protection the environment (Smith 2003: 13-7). ${ }^{33}$

Though pragmatist thinking does not preclude a more fundamental de-centering of human beings and has indeed sympathies for these more radical perspectives, a weak, non-chauvinist anthropocentrism may be a fit starting position for environmental pragmatism. It takes up the legitimate criticism of post-humanist approaches, is aware of the human embeddedness in nature, compassionate to fellow beings and sensitive to the interrelations of humans and non-humans (Honnacker 2020: 79-81).

\subsection{Conclusion: Ecological Meliorism}

64 The question of how much time is left for effective collective action and a fundamental change of policy continues to be central in the environmentalist debate and grows even more acute. Looking back at more than fifty years of warnings and appeals, and facing horrific news about global warming like extreme weather phenomena or quickly melting poles and permafrost, it is increasingly difficult to trust in the ability of human societies, whether democratic or not, to undergo a real transformation. Among environmentalists, there is a "sense of growing doom and frustration at the lack of progress and social mobilization, or institutional planning, for the transition to a lowcarbon or post-carbon society and economy" (Barry 2014: 166). ${ }^{34}$ The latest philosophical proposals are no longer advocating a deep, but a dark ecology (Morton 2018).

65 Drawing on the Jamesian notion of meliorism, I suggest an outlook that is neither optimist nor pessimist with regard to the outcome of the ecological crisis. Whereas optimism may lead to inaction or promethean anti-politics, pessimism may result in an anti-humanist nihilism, an "all is lost" attitude and a dismissal of all transformational efforts. Both options, though, seem to lead to inhumane consequences, and "at times it 
is hard to know which is the more unsettling: the cosy and comforting accounts of reformist 'optimists' [...] or the shocking and frightening views of radical 'pessimists"' (Barry 2014: 170). Meliorism, in contrast, is an existential commitment that comes with an in-built "call to action" - and this call relies not on complete certainty or evidence but operates into the unknown: the limited human capacity of determining "what has to be done" is fully acknowledged.

Speaking very generally, pragmatism follows a negativist account in terms of methodology. Instead of starting with a definite positive ideal, the focus is on disturbances, disfunctions and failures, that is, on problematic situations that has to be solved, overcome, or changed to the better. The underlying minimal rationale thus is preventing harm. ${ }^{35}$ Such a negativist account of green politics obviates all too authoritarian prescriptions, since it does without pre-fixed solutions or goals or even a definition of the "good life." Rather, it strives for provisional and dynamic solutions by tackling concrete harmful and exploitive structures that hinder well-being. In order to identify relevant problems, these structures have to be made visible, they need a "desequestering" (Barry 2014: 165). Looking for concrete deficits and ecologically harmful practices, for example with regard to $\mathrm{CO}_{2}$-emitters or unsustainable chains of production, may lead to better procedures than rather abstract discussions about future sustainability. ${ }^{36}$

What is more, the thoroughgoing pragmatic pluralism may be helpful to overcome a serious hindrance to environmental action. Not only with regard to strategies (conservation vs. preservation), or priorities (wind power vs. nuclear power, wind power vs. bird protection), but also to the very grounding of environmental reasoning, we find conflicting views that have to be reconciled: "Value conflict is at the heart of environmental politics." (Smith 2003: 1). Instead of demanding "ethical monism, the belief that there is a single, comprehensive and systematic theory that will eliminate indeterminacy and value conflict" (Smith 2003: 18; 18-21), accepting value pluralism could be fostering common action even in the case of conflicting ethical judgements and indeterminate reasoning. This means to accept the potential incompatibility and incommensurability of values: there are situations in which values exclude each other's fulfilment and there might be even no common ground on how to evaluate this conflict (Smith 2003: 18-26). Hence, ecological meliorism is sensitive to the conflicting interests in the public discourse that need to be addressed and reconciled - which can be said to be the tragic core of the democratic project. ${ }^{37}$ Beyond the political arena, its sense for the tragic is able to cope with the loss of ways of life and the pain transformational processes can effect (an issue that is often overlooked in environmental discourse): "Letting go" and stopping familiar practices may be the real challenge (Barry 2014: 166).

Though ecological meliorism aims at transformational action with all human effort, it abstains from progressivist thinking. As little as humanity can rely on an intervening God to save the world, it should rely on a future technological panacea. Rather, ecological meliorism rises awareness of the human contingency: Following an important insight from non-anthropocentric environmentalism, it gears towards overcoming human chauvinism and promethean thinking and adheres to a sense for the vulnerability and dependence of human beings. Meliorist action thus involves a particular, motivating kind of hope: "It is important to say what hope is not: it is not the belief that everything was, is, or will be fine. The evidence is all around us of 
tremendous suffering and tremendous destruction. [...] It's also not a sunny everythingis-getting-better narrative, though it may be a counter to the everything-is-gettingworse narrative. You could call it an account of complexities and uncertainties, with openings." (Solnit 2016: xi-xii)..$^{38}$

It is not "too late" to perform social, economic and cultural transformations - though the ecological crisis cannot be prevented anymore. It is already happening. Still, we have all reason (and the responsibility) to strive for the least harmful scenario. There is so much left to lose and to fight for. Deepening democracy and endorsing ecological meliorism will support that struggle.

\section{BIBLIOGRAPHY}

Aaltola Elisa, (2010), "Green Anarchy: Deep Ecology and Primitivism," in Benjamin Franks \& Matthew Wilson (eds.), Anarchism and Moral Philosophy, Basingstoke, Palgrave Macmillan.

BARRY John, (2002), "Vulnerability and Virtue. Democracy, Dependency, and Ecological Stewardship," in Ben A. Minteer \& Bob Pepperman Taylor (eds.), Democracy and the Claims of Nature. Critical Perspectives for a New Century, Lanham, Md., Rowman and Littlefield, 133-52. BARRY John, (2014), “Green Political Theory,” in Vincent Geoghegan \& Rick Wilford (eds.), Political Ideologies - An introduction, New York, Routledge, 153-78.

BUCHSTEIN Hubertus, (2012), "Umweltpolitik in Diktaturen und Demokratien. Neue Befunde zu einer alten Kontroverse," Braune Ökologen. Hintergründe und Strukturen am Beispiel MecklenburgVorpommerns, Band 26, ed. by Heinrich-Böll-Stiftung / Heinrich-Böll-Stiftung MecklenburgVorpommern, 51-61.

CUDWORTH Erika \& Stephen HOBDEN, (2011), Posthuman International Relations. Complexity, Ecologism and Global Politics, London, Zed Books.

DEWEY John, (1991), The Public and its Problems, Athens, Ga., Swallow Press, Ohio University Press.

DEWEY John, (2002), "Pragmatismus und Pädagogik [Konkretes und Abstraktes Denken]," in Ekkehard Martens (ed.), Philosophie des Pragmatismus, Stuttgart, Reclam, 205-14.

DRYZEK John, (1987), Rational Ecology: Environment and Political Economy, Oxford, Basil Blackwell.

ECKERSLEY Robyn, (2000), “Deliberative Democracy, Ecological Representation and Risk: Towards a Democracy of the Affected," in Michael Saward (ed.), Democratic Innovations: Deliberation, Representation and Association, London/New York, Routledge, 117-45.

ECKERSLEY Robyn, (2004), The Green State: Rethinking Democracy and Sovereignty, Cambridge, Ma., The MIT Press.

FERRY Luc, (1995), The New Ecological Order, Chicago, University of Chicago Press.

FRASER Nancy, (1992), "Rethinking the Public Sphere: A Contribution to the Critique of Actually Existing Democracy," in Craig Calhoun (ed.), Habermas and the Public Sphere, Cambridge, Ma., The MIT Press, 107-42. 
Goodin Robert E., (1992), Green Political Theory, Cambridge, Polity Press.

GOTTLIEB Roger, (2019), Morality and the Environmental Crisis, Cambridge, Cambridge University Press.

GRAY John, (2007), Straw Dogs. Thoughts on Humans and Other Animals, New York, Farrar, Straus and Giroux.

GREEN Judith M., (1998), Pragmatism and Social Hope. Deepening Democracy in Global Context, New York, Columbia University Press.

HABERMAS Jürgen, (1968), "Verwissenschaftlichte Politik und öffentliche Meinung," in Id., Technik und Wissenschaft als "Ideologie," Frankfurt-a.-Main, Suhrkamp, 120-45.

HABERMAS Jürgen, (1988), Between Facts and Norms: Contributions to a Discourse Theory of Law and Democracy, Cambridge, Ma., The MIT Press.

HAMPE Michael, (2008), "Szientistische und naturalistische Tendenzen im Pragmatismus," in Andreas Hetzel, Jens Kertscher \& Marc Rölli (eds.), Pragmatismus - Philosophie der Zukunft?, Weilerswist, Velbrück Wissenschaft, 121-9.

HONNACKER Ana, (2018), "Man as the Measure of All Things: Pragmatic Humanism and Its Pitfalls," in Anthony B. Pinn (ed.), Humanism and the Challenge of Difference, New York, Palgrave Macmillan, $135-64$.

HONNACKER Ana, (2020), "Pragmatic Humanism and the Posthumanist Challenge: Between Biocentrism and the New Human Being," Contemporary Pragmatism, 17, 70-84.

ноок Sidney, (1974), Pragmatism and the Tragic Sense of Life, New York, Basic Books.

HORN Eva \& Hannes BERGTHALLER, (2019), Anthropozän zur Einführung, Hamburg, Junius.

HUMPHREY Mathew, (2007), Ecological Politics and Democratic Theory. The Challenge to the Deliberate Ideal, New York, Routledge.

JÄNICKE Martin, (1996), "Democracy as a Condition for Environmental Policy Success," in William M. Lafferty \& James Meadowcroft (eds.), Democracy and the Environment, Cheltenham, Edward Elgar, 71-85.

KATZ Eric, LIGHT Andrew \& David ROTHENBERG, (2000), "Introduction: Deep Ecology as Philosophy," in Id. (eds.), Beneath the Surface. Critical Essays in the Philosophy of Deep Ecology, Cambridge, Ma./ London, The MIT Press, ix-xxiv.

KENNEDY Joe, (2018), Authentocrats. Culture, Politics, and the New Seriousness, London, Watkins Media. KITCHER Philip, (2011), Science in a Democratic Society, Amherst, Prometheus Books.

KITCHER Philip \& Evelyn Fox KELLER, (2017), The Seasons Alter. How to Save Our Planet in Six Acts, New York/London, Liveright.

LATOUR Bruno, (1995), Wir sind nie modern gewesen. Versuch einer symmetrischen Anthropologie, Berlin, Akademie Verlag.

LATour Bruno, (2015), Das Parlament der Dinge. Für eine politische Ökologie, Frankfurt-a.-Main, Suhrkamp.

LEGGEWIE Claus \& Harald WELZER, (2010), Das Ende der Welt, wie wir sie kannten. Klima, Zukunft und die Chancen der Demokratie, Bonn, Bundeszentrale für politische Bildung (Lizenzausgabe für die Bundeszentrale für politische Bildung). 
LEIST Anton, (2005), “Ökologische Ethik II: Ökologische Gerechtigkeit: Global, intergenerationell und humanökologisch," in Julian Nida-Rümelin (Hg.), Angewandte Ethik. Die Bereichsethiken und ihre theoretische Fundierung. Ein Handbuch, Stuttgart, Kröner Verlag, 426-512.

LEOPOLD Aldo, (1949), A Sand County Almanac and Sketches Here and There, New York/Oxford, Oxford University Press.

LIGHT Andrew, (2002), "Restoring Ecological Citizenship," in Ben A. Minteer \& Bob Pepperman Taylor (eds.), Democracy and the Claims of Nature. Critical Perspectives for a New Century, Lanham, Md., Rowman and Littlefield, 153-72.

MEDINA José M., (2015), “The Will Not to Believe: Pragmatism, Oppression, and Standpoint Theory," in Erin C. Tarver \& Shannon Sullivan (eds.), Feminist Interpretations of William James, University Park, Pennsylvania State University Press, 255-60.

MINTEER Ben A., (2005), “Environmental Philosophy and the Public Interest: A Pragmatic Reconciliation," Environmental Values, 14 (1), 37-60.

MINTEER Ben A., (2009), "Unity among Environmentalists? Debating the Values-Policy Link in Environmental Ethics," in Id. (ed.), Nature in Common? Environmental Ethics and the Contested Foundations of Environmental Policy, Philadelphia, Temple University Press, 3-17.

MORTON Timothy, (2018), Dark Ecology: For a Logic of Future Coexistence, New York, Columbia University Press.

MULGAN Tim, (2011), Ethics for a Broken World: Imagining Philosophy After Catastrophe, New York, Routledge.

NAESS Arne, (1989), Ecology, Community and Lifestyle. Outline of an Ecosophy, Cambridge, Cambridge University Press.

NORTON Bryan G., (1984), “Environmental Ethics and Weak Anthropocentrism," Environmental Ethics: An Interdisciplinary Journal Dedicated to the Philosophical Aspects of Environmental Problems, 6 (2), 131-48.

NORTON Bryan G., (1991), Toward Unity Among Environmentalists, New York, Oxford University Press. NORTON Bryan G., (2002), "Democracy and Environmentalism. Foundations and Justifications in Environmental Policy," in Ben A. Minteer \& Bob Pepperman Taylor (eds.), Democracy and the Claims of Nature. Critical Perspectives for a New Century, Lanham, Md., Rowman and Littlefield, 11-32. ORESKES Naomi \& Erik M. CONWAY, (2012), Merchants of Doubt. How a Handful of Scientists Obscured the Truth on Issues from Tobacco Smoke to Global Warming, London u.a., Bloomsbury.

PLumwood Val, (2000), "Deep Ecology, Deep Pockets, and Deep Problems: A Feminist Ecosocialist Analysis," in Eric Katz, Andrew Light \& David Rothenberg (eds.), Beneath the Surface. Critical Essays in the Philosophy of Deep Ecology, Cambridge, Ma./London, The MIT Press, 59-84.

PÖTTER Bernhard, (2010), Ausweg Ökodiktatur? Wie unsere Demokratie an der Umweltkrise scheitert, München, Oekom.

RADCLIFFE James, (2002), Green Politics. Dictatorship or Democracy?, Basingstoke/New York, Palgrave. RADKAU Joachim, (2011), Die Ära der Ökologie. Eine Weltgeschichte, München, Beck.

RADKAU Joachim, (2012), Natur und Macht. Eine Weltgeschichte der Umwelt, München, Beck.

ROUTLEY Richard, (1973), "Is There a Need for a New, an Environmental Ethic?," Proceedings of the XVth World Congress of Philosophy, 205-10. 
SMITH Graham, (2003), Deliberative Democracy and the Environment, London, Routledge.

SOLNIT Rebecca, (2016), Hope in the Dark. Untold Histories, Wild Possibilities, Edinburgh/London, Canongate Canons.

VINCENT Andrew, (2003), “Green Political Theory,” in Richard Bellamy \& Andrew Masson (eds.), Political Concepts, Manchester, Manchester University Press, 182-95.

WESTRA Laura, (1993), "The Ethics of Environmental Holism and the Democratic State: Are They in Conflict?," Environmental Values, 2, 125-36.

WESTRA Laura, (1998), Living in Integrity: A Global Ethics to Restore a Fragmented Earth, Lanham, Md., Rowman \& Littlefield Publishers.

WHITE Lynn, (1967), “The Historical Roots of Our Ecological Crisis,” Science, 155 (3767), 1203-07.

ZIMMERMANN Michael, (1995), "The Threat of Ecofascism," Social Theory and Practice, 21 (2) (Special Issue: "The Environmental Challenge to Social and Political Philosophy"), 207-38.

ZIMmermann Michael, (2000), "Possible Political Problems of Earth-Based Religiousity," in Eric Katz, Andrew Light \& David Rothenberg (eds.), Beneath the Surface. Critical Essays in the Philosophy of Deep Ecology, Cambridge, Ma./London, The MIT Press, 169-94.

\section{NOTES}

1. See Pötter (2010: 77) - although in my experience these kinds of statements, often uttered on the sidelines of environmentalist's meetings, are far from full-blown authoritarian fantasies.

2. Interview with Der Spiegel, 13.09.2019 (https://www.spiegel.de/wissenschaft/technik/ extinction-rebellion-gruender-roger-hallam-wenn-eine-gesellschaft-so-unmoralisch-handeltwird-demokratie-irrelevant-a-1286561.html), my translation. Hallam was arrested soon after the interview for trying to disrupt air traffic with a drone at Heathrow Airport. After several controversial statements on the Holocaust, XR Germany distanced itself from Hallam.

3. One of the three declared aims of XR is a leading political role for citizens' assemblies, see This Is Not a Drill: An Extinction Rebellion Handbook (2019), London, Penguin Books.

4. See Pötter (2010: 23).

5. Even more, it is only plausibly that these emotional commitments are instrumentalized in order to give right-wing positions a friendly face and make them more accessible. One of the most influential works of nature writing, "Tarka the Otter," published on 1927, was written by Henry Williamson who supported the British fascists. For a more detailed critique of this "ethnography" of the (new) nature writing see chapter IV in Kennedy (2018).

6. A more detailed critique of environmental activism that rests on ecological identity politics is given in Light (2002: 158-65).

7. Postulating that "certain types of politics or morality are natural in themselves" (Vincent 2003: 189) comes with possibly uncomfortable political consequences: "it is not at all clear why authoritarian, tribal, or many other types of political community cannot be natural." (Ibid. 191).

8. The survivalist strand reached its peak in the 1970ies, then mainly addressing the problem of limited resources, and later shifted to ecocentrist view, see Humphrey (2007: 5).

9. Who actually named their magazine "Do or Die" (1992-2003) and follow the slogan "No Compromise in Defense of Mother Earth!".

10. On the surprisingly small role of violence in the green movement see Radkau (2011: 409-95) and Gottlieb (2019: 182-6). For a further discussion of the status of direct action see Humphrey (2007: 63-77). 
11. For a detailed discussion of this anti-democratic epistemological elitism in Westra's work see Norton (2002: 23-6).

12. For a discussion of centralism vs. decentralism in environmental politics see Radcliffe (2002: 21-45).

13. Mostly, it remains unclear how the global population is to be diminished. Whereas using a "social technology" like raising the average educational level, especially for women seems unproblematic and even in line with other goals like self-determination, other methods could easily come close to eugenic considerations. Assuming that it will happen "naturally" (by disease, or more and more inimical environmental conditions, and/or the wars that will be induced by the fight for resources) may save from putting it on the political agenda yet is not less cynical and anti-humanist, take for example Lovelocks "vision of a technological 'survivalist' society [...] a techno-optimistic progressive society that is at one and the same time socially regressive" (Barry 2014: 170).

14. Deep ecology, for example, as well as primitivism, employ such an anti-constructivist realism (Aaltola 2010: 168-9).

15. For an overview of non-anthropocentrism in environmental philosophy see Minteer (2009: 3-8), for the debate anthropocentrism vs. non-anthropocentrism see Smith (2003: 8-13).

16. Beyond holding it to be more plausible, another reason for defending the anthropocentric outlook is finding it to be more promising with respect to efficiency. Yet one could as well argue that on the level of political goals, both positions converge (Norton 1991; Minteer 2009: 8-13).

17. An interesting attempt of adapting legal terminology and including traditional knowlegde of ecosystems and the relation of humans and non-humans is made in the Bolivian and Ecuadorian law, which grants rights to pachamama, a concept stemming from indigenious cosmology (Horn \& Bergthaller 2019: 108-13).

18. See, for example, Gottlieb (2019: 41-3).

19. A complete reversal of the scenario would allow for getting rid of mankind in total. However, apart from extreme cases like the Unabomber, whose anti-civilizatory ideal of nature without humankind led him to acts of terrorism, extremely misanthropic positions, such as the idea of humankind as a planetary disease that has to be cured, are rarely seriously advocated in environmental philosophy or influential in political activism. Even the explicit antinatalism inspired by deep ecology that can be found in the Voluntary Human Extinction Movement demands only critical reflection on procreation, and Westra and most other proponents of holistic environmentalism take "survival" for the primary value. Leist makes the priority of human life precondition for an ecological democratic community (Leist 2005: 440-1).

20. Comparing actual performances of democratic and autocratic regimes in terms of addressing environmental problems, democracies outmatch autocracies (Buchstein 2012: 56-8, see also Jänicke 1996).

21. The capitalist framework of political actions is often identified as one of the major problems, see for example Cudworth \& Hobden (2011: 118-25).

22. A political strategy Bruno Latour tellingly denotes as "smuggling" (Latour 2015: 137, see also 21-30; Latour 1995: 22-67). For an earlier discussion of technocratic or decionist models which tend to undermine democracy and the pragmatic concept of a critical mutual relation of science and politics as an alternative see Habermas (1968).

23. Still, the willingness to sacrifice democratic values in order to strive for an assumed (scientific) necessity is not completely alien to pragmatism. F.C.S. Schiller's support of fascism was mainly motivated by his belief in its capabilities of building a "eugenic state," whereas he considered democracies incapable of doing what he identified as necessary to create a better, or at least not declining, society (Honnacker 2018: 152-4). Also Peirce and, partly, James displayed an understanding of their philosophy analogous to positivistic science - a scientistic selfmisconception, as Michael Hampe shows, see Hampe (2008). 
24. Following Dewey, Philip Kitcher highlights the role of science communication/education and a "well-ordered science" for a democratic society, see, for example, Kitcher (2011: 169-92).

25. See Smith (2003: 29-50), Leist (2005: 493-7).

26. For example, according to Westra, we have to live up to the "integrity principle," if necessary by force (Westra 1993).

27. Habermasian discourse ethics and his concept of the public sphere that is marked by open access, participatory parity and social equality may be a starting point here, see, for example, Habermas (1988). For a critical extrapolation see, for example, Fraser (1992).

28. For example, José Medina's "guerilla pluralism" provides a fruitful concept for radically plural collective learning processes, see Medina (2015).

29. For the role of active interaction and concretion in learning see Dewey (2002). The role of experience and emotional bonding for developing an ethical relationship to nature is also highlighted in Aldo Leopold's land ethics, see Leopold (1949).

30. Following, for example, the works of Iris Marion Young.

31. The Rawlsian deliberative model of liberal democracy may also prove too narrow, for example, with regard to disruptive environmentalist strategies and the burden public reasoning puts on dissenting groups (Humphrey 2007: 98-101, 115-38). Robyn Eckersley's “critical political ecology" for example demands for a post-liberal democratic state (Eckersley 2004).

32. See Gottlieb (2019: 62-6, 71-7). Gottlieb points to the basic human ability of response-ability beyond the verbal: "If we can respond politically to babies crying from hunger, so we can respond to poisoned fish and coral bleached white." (Ibid.: 77)

33. Historically, the most effective motivation for acting against harmful environmental practices has been health concerns. Whether in the case of DDT, CFC or nuclear energy, the fear of health-damaging effects, prominently cancer, led to massive public protests and change of policies, see Radkau (2011: 405-8), and Radkau (2012: 16-7, 299-305).

34. Similarly Gottlieb (2019: 185-6): "We face a series of critical, often lethal, and for a good deal of humanity perhaps even existential threats. [...] It is not surprising that 'feeling overwhelmed' is a common condition among environmentalists."

35. The "maximal" (rather affirmative) version of this negative rationale is the ideal of flourishing which can also be found in the pragmatist tradition. Though the ideal of flourishing in itself may be abused when it is substantially spelled out and fixed to a particular meaning (Barry 2014: 162-3), the pluralist pragmatist articulation of flourishing is less determinate and thus less vulnerable to authoritarian highjacking.

36. John Barry suggests a "politics of actually existing unsustainability," analogous to the idea that starting political action from injustice rather than from a theory of justice is more promising, see Barry (2014: 159-65).

37. For a thoroughgoing study of the tragic in pragmatism see Hook (1974).

38. This idea of hope also underlines the plasticity of the world which is central to the meliorist attitude: "Hope is an embrace of the unknown and the unknowable, [...] the belief that what we do matters." (Solnit 2016: xii). 


\section{ABSTRACTS}

As the ecological crisis becomes increasingly pressing, the relation of environmentalism and democracy is spotlighted with new instancy. On one hand, the capability of present democratic governments to take adequate political action is seriously questioned. On the other hand, environmentalism is charged of being anti-democratic. This paper, in a first step, examines the "green" criticism of and sometimes actual departures from democracy. Drawing on that analysis as well as a pragmatist concept of democracy, the elements of an "ecological democracy" will be outlined in a second step. Democracy, then, is not only a way of collective-problem solving, but also a form of life that has an intrinsic value, even in the face of unresolvable problems and failure. Striving for transformation and the best possible scenario nevertheless, finally, demands an attitude of ecological meliorism, which will be briefly outlined.

\section{AUTHOR}

\section{ANA HONNACKER}

Universität Hildesheim

post[at]ana-honnacker.de 